\title{
ESTOPPEL UNDER THE UNIFORM DIVORCE RECOGNITION ACT IN CALIFORNIA
}

A divorce obtained without domicile of the plaintiff in the rendering state is invalid and subject to collateral attack in other jurisdictions. ${ }^{1}$ However, using the language of estoppel, many states have recognized certain kinds of conduct on the part of the party who would attack the decree as barring his challenge of it. ${ }^{2}$ The party who procured the divorce on simulated domicile, ${ }^{3}$ or who aided another in doing so, ${ }^{4}$ or who remarried in reliance upon such a decree ${ }^{5}$ has been held estopped from raising the issue of its invalidity.

To provide expression for a strict policy of nonrecognition of "quickie" divorces, the Commissioners on Uniform State Laws drafted the Uniform Divorce Recognition Act. ${ }^{6}$ The Act has been adopted in California and several other states. ${ }^{7}$ It provides that a divorce obtained im another jurisdiction shall be of "no force or effect" in this state if both parties thereto were domiciled here at the tine the proceeding for the divorce was commenced. ${ }^{8}$ The particular language used was intended to eliminate the estoppel doctrine from the area of divorce recognition; the Commissioners felt that to allow estoppel in a case where a decree was challenged on domicile grounds was to give some "force or effect" to the decree. ${ }^{9}$ It will be attempted in this comment to ascertain what, if any, room is left for the operation of the estoppel doctrine in California since the adoption of the Üniform Act.

\section{THE ACT, ESTOPPEL, AND FULL FAITH AND CREDIT}

In at least one class of cases in which state courts have applied the estoppel doctrine, the Uniform Act may be expected to produce no change.

1 Williams v. North Carolina (II), 325 U.S. 226 (1945).

2 The rule is stated in Restatentent, Confuct of Laws $\$ 112$ (1934):

The validity of a divorce decree cannot be questioned in a proceeding concerning any right or other interest arising out of the marital relation, either by a spouse who has obtained such decree of divorce from a court which had no jurisdiction, or by a spouse who takes advantage of such decree by remarrying.

Typical cases in accord are In re Brandt's Estate, 67 Ariz. 42, 190 P.2d 497 (1948); Smith v. Smith, 206 Okla. 206, 242 P.2d 436 (1952); Romanski Estate, 354 Pa. 261, 47 A.2d 233 (1946); Starbuck v. Starbuck, 173 N.Y. 503, 66 N.E. 193 (1903) ; see Caldwell v. Caldwell, 298 N.Y. 146,81 N.E.2d 60 (1948), to the effect that, while a party may be estopped from challenging the invalid decree of a sister state, there is never in New York an estoppel to the challenge of a Mexican "mail order" divorce.

3 Watson v. Watson, 39 Cal.2d 305, 246 P.2d 19 (1952); Rediker v. Rediker, 35 Cal.2d 796, 221 P.2d 1 (1950).

4 Bernheimer v. Bernheiner, $103 \mathrm{Cal}$. App.2d 643, 230 P.2d 17 (1951).

5 Bruguiere v. Bruguiere, 172 Cal. 199, 155 Pac. 988 (1916).

69 UNIFORM LAWS, ANNOTATED 364 (1951).

7 CaL. CIv. Code $\$ \S 150-150.4$. Substantially the same statute is found in NEb. Rev. Stat. $\$ \S 42-341$ to $42-344$ (1952), N. H. Rev. Laws c. 339-A, $\$ \$ 1-4$ (1949), R. I. GeN. Laws c. 2268 (1949), S.C. Code $\$ \S 20-131$ to 20-134 (1952), WASH. Rev. CodE $\$ \S 26.08 .200,26.08 .210$ (1949), and Wis. STAT. $\$ 247.22$ (1953).

8 CAI. CIV. CODE $\$ 150.1$.

9 9 UNIFORMI LAWS, ANNOTATED 370 (1951). 
Where both spouses have participated in procuring a divorce, state courts have recognized the propriety of estopping them from attacking the decree, ${ }^{10}$ unless some special reason, such as fraud practiced by one spouse upon the other in connection with the procurement of the decree, ${ }^{11}$ appears to justify allowance of the attack. Furthermore, a decree obtained through participation of both spouses is entitled to full faith and credit under Article IV of the Constitution of the United States. ${ }^{12}$ Although the Uniform Act has not as yet faced a constitutional test, it would seem fair to assume that it would be held unconstitutional if applied to impeach a decree obtained on simulated domicile in a sister state, if both spouses participated in procuring the decree and there was opportumity to litigate the issue of domicile before the court which rendered it. ${ }^{13}$

Thus the Act would seem to have real impact ${ }^{14}$ upon the state law of estoppel only when applied in a challenge of a decree obtained without participation of both spouses. In such a case the risk of the Act's being held unconstitutional seems small, for the Supreme Court has recently held an

10 Loud v. Loud, 129 Mass. 14 (1880); Judkins v. Judkins, 22 N.J. Super. 516, 92 A.2d 120 (Ch. 1952); Woodhouse v. Woodhouse, 20 N.J. Super. 229, 89 A.2d 707 (App. Div. 1952).

11 Lawler v. Lawler, 2 N.J. 527, 66 A.2d 855 (1949); Roberts v. Roberts, 81 Cal. App.2d 871,185 P.2d 381 (1947).

12 Sherrer v. Sherrer, 334 U.S. 343 (1948); Coe v. Coe, 334 U.S. 378 (1948); Johnson v. Muelberger, 340 U.S. 581 (1951).

The Supreme Court has not yet made a distinction between a divorce obtained in an actual adversary proceeding and one obtained by collusion between the spouses. In either case there is participation and opportunity to litigate the issue of plaintiff's domicile in the divorce forum, yet under a policy of discouraging the "quickie" divorce only the former would merit full faith and credit. Staedler v. Staedler, 6 N.J. 380, 78 A.2d 896 (1951).

13 So far only parties, Sherrer v. Sherrer, supra note 12, and their privies, Johnson v. Muelberger, supra note 12, have been barred under the full faith rule. However, dicta have extended the rule to govern the case where the defendant has defaulted after personal service of process in the divorce jurisdiction; to bar third parties, along with the spouses, from attacking a decree obtained where both spouses participated; and generally to prohibit attacks upon a sister-state decree where it is not open to collateral attack in the state where rendered. See, for example, the language in Johnson v. Muelberger, supra note 12, at 589, part of which reads:

When a divorce cannot be attacked for lack of jurisdiction by parties actually before the court or strangers in the rendering state, it cannot be attacked by them anywhere in the Union.

Despite such dicta, the law does not seem clear as to when a decree will merit full faith and credit. A legislative reaction to this uncertainty may be found in Senator McCarran's "Bill to Further Implement the Full Faith and Credit Clause of the Constitution," 99 Cono. REc. 4732 (1953). The bill would accord mandatory full faith to any decree whicls is final and valid in the state where rendered, contains recitals that the state's jurisdictional prerequisites were met, and was rendered in the last state where the spouses were domiciled together or where the defendant was personally subject to the court's jurisdiction or made a general appearance in the action. The recitals of the decree are made conclusive, except in cases involving fraudulent conduct of the successful party "which was practiced during the course of an actual ad. versary trial of the issues joined and the effect of which was directly and affirmatively to mislead the defeated party to his injury after lie announced that he was ready to proceed with the trial." The bill has twice passed the Senate and been introduced in the House Committee on the Judiciary, which apparently has not yet acted upon it.

14 The Act has another impact in the prima facie evidence of continued domicile in California provided in Car. Crv. CODE $\$ 150.2$. This section places so heavy a burden of proving domicile in the divorce forum upon the party defending the decree as to amount, conceivably, to a presuinption of the invalidity of the decree. In this respect the Act may conflict with the presumption of validity of a judicial decree exemplified in Cook v. Cook, 342 U.S. 126 (1951). 
ex parte decree open to collateral attack in another jurisdiction upon an averinent that the spouse who procured the decree had not established a bona fide domicile in the divorce forum. ${ }^{15}$

Because the state law of recognition is thus left to operate primarily in the area ${ }^{16}$ of ex parte decrees, this comment will be restricted, henceforward, to a discussion of the effect of the Uniform Act upon the estoppel doctrine with regard to such decrees, and divorces obtained with participation will be treated only by way of analogy.

\section{OTHER DIVORCE RECOGNITION STATUTES}

The weakness in the state law of recognition of the ex parte divorce proposed to be cured by the Uniform Act was the propensity of many states to use the estoppel doctrine to bar collateral attack when the challenger had himself procured the decree or had married in reliance upon it. ${ }^{17}$ To support their position that the "no force or effect" provision of the Act would eliminate estoppel in such cases, the Commissioners stated that two other states, Massachusetts and New Jersey, had so interpreted and apphed their respective "no force or effect" nonrecognition statutes. ${ }^{18}$ A search of the history of those enactments, however, reveals a considerable number of cases which do not support the Commissioners' statement.

It may be conceded that the Massachusetts statute ${ }^{19}$ has been strictly enforced and that the courts of that state have stated strongly that there is no estoppel to a collateral attack upon a sister state decree. ${ }^{20}$ Yet, where a wife appeared in her husband's divorce action in another state, executed a release reciting the decree therein obtained by him, and, for a pecuniary

15 Rice v. Rice, 336 U.S. 674 (1949). An ex parte decree, as used in this comment, is one obtained without personal service of process on the defendant.

10 This restricted area of operation was apparently recognized by the California legisiature in the addition of a "saving clause" to the California version of the statute. CAL. Crv. Code $\S 150.4$ :

The application of this article is limited by the requirement of the Constitution of the United States that full faith and credit shall be given in each state to the public acts, records and judicial proceedings of every other state.

179 UNTFORAr Laws, ANrotated at 370-371 (1951):

A number of decisions refuse to allow attack upon the validity of a foreign divorce by one who obtained it, or who has appeared in the proceedings brought against bim, with or without contesting the foreign court's jurisdiction, or who has assented to the divorce or has neglected to attack it for a considerable time. [Citations omitted.] The enunciation of policy proposed by this section will close, to the extent permitted under the Coe and Sherrer cases, the door to evading the validity [sic; the Coinmissioners evidently meant "invalidity"] of the tourist divorce which the decisions first cited above leave ajar.

18 Id. at 371.

19 Mass. ANn. Laws c. $208, \$ 39$ (1933):

... [I] $\mathrm{f}$ an inhabitant of this commonwealth goes into another jurisdiction to obtain a divorce for a cause occurring here while the parties resided here, or for a cause which would not authorize a divorce by the laws of this cominonwealth, a divorce so obtained shall be of no force or effect in this commonwealth.

20 Andrews v. Andrews, 176 Mass. 92, 57 N.E. 333 (1900) ; Coe v. Coe, 316 Mass. 423, 55 N.E.2d 702 (1944), reversed, 334 U.S. 378 (1948), on grounds that the decree merited full faith and credit. 
consideration, discharged all her claims upon him and his estate, she was barred from challenging the decree in a later action in Massachusetts and from treating his subsequent marriage as a violation of his marital obligations to herself. The court based its decision upon the theory that her conduct was a "connivance at, or acquiescence in," his subsequent marriage and it disclaimed the applicability of estoppel principles notwithstanding that those principles would have indicated the same result. ${ }^{21}$ Although the divorce in this case was not obtained ex parte, still the decision represents the giving of what the Commissioners apparently feel to be some force and effect ${ }^{22}$ to an invalid decree under a statute which would refuse such a decree any force and effect. ${ }^{23}$

In another case, the Massachusetts court expressly recognized the apphicability of estoppel principles. ${ }^{24}$ Here the husband obtained an ex parte decree in a state other than that in which the wife resided and without legal notice to her. ${ }^{25}$ Upon learning of the decree, she remarried in reliance upon it, and for twenty-five years she took no steps to challenge its validity or to assert her rights in her first marriage. The court held her estopped from denying the validity of the divorce and from claiming a widow's allowance from the estate of the husband who had obtained the decree.

More extensively than Massachusetts, the New Jersey courts have found it consistent to allow estoppel while denying force or effect to a sisterstate decree obtained upon simulated domicile. Despite the presence of a

21 Loud v. Loud, 129 Mass. 14 (1880). See aso, e.g., Chapman v. Chapman, 224 Mass. 427, 113 N.E. 359 (1916); and Langewald v. Langewald, 234 Mass. 269, 125 N.E. 566 (1920). In the Chapman case, the wife had remarried in reliance upon the husband's invalid sister state divorce, and the court held her barred from claiming a widow's share in his estate. The opinion contained the statement:

This result is supported by decisions in many other jurisdictions, though the grounds upon which they are put are not identical in all the cases, and perhaps are not such in all instances as we should adopt. Collectively, they disclose a strong disposition on the part of the courts not to aid one in the position of this appellee. 224 Mass. at 434, 113 N.E. at 362.

The court then cited, among many other cases which reached similar results, Bruguiere v. Bruguiere, 172 Cal. 199, 155 Pac. 988 (1916), which applied estoppel. The Massachusetts court, then, although disclaiming the estoppel doctrine, bas decided cases in a manner consistent with it.

229 UNIFORM LAWS, ANNOTATED at 371 (1951).

23 The Commissioners note that even under a nonrecognition statute an attack upon a sister-state decree might be barred in a "proper case." Id. at 371. The only example of such a case cited by the Commissioners is Langewald v. Langewald, 234 Mass. 269, 125 N.E. 566 (1920). In that case, however, there was an appearance by the wife in the husband's Wyoming divorce action and acceptance by her of a cash settlement in consideration of the divorce. Although the Massachusetts court held her barred by her own connivance from questioning the decree in Massachusetts despite the nonrecognition statute, such a case would probably now be decided on full faith and credit principles. (See text at notes 12-13 supra.) One may thus question whether a "proper case" could ever arise wherein the Commissioners would recognize the propriety of a state-involed estoppel.

24 Parmelee v. Hutchins, 238 Mass. 561, 131 N.E. 443 (1921).

25 The decree in this case was void for want of fair notice to the defendant spouse. The court applied estoppel, and it cited Chapman v. Chapman, 224 Mass. 427, 113 N.E. 359 (1916), where the decree was void for lack of domicile. The problem seems the same regardless of why the rendering court is without jurisdiction. It appears inconsistent to allow estoppel when the decree is void for any reason other than lack of domicile while denying the defense in that one instance. 
nonrecognition statute, ${ }^{26}$ laches ${ }^{27}$ connivance in the procurenient of the foreign decree,$^{28}$ and marriage in reliance upon the invalid decree ${ }^{29}$ have all been held to bar a collateral attack upon the decree, provided the challenger is gnilty of such inequitable conduct and the defender is innocent. ${ }^{30}$

The judicial interpretation of the Massachusetts and New Jersey statutes seems to justify the conclusion that a preclusion of estoppel is not a necessary consequence of a "no force or effect" statute. If this is so, whether the Uniform Act is to preclude the further application of estoppel in California divorce recognition cases would seem to depend on the legislative history of the statute and, perhaps, its relationship to pre-existing California law, and not on its use of the phrase "no force or effect."

\section{CAITFORNIA LAW}

\section{Pre-statute: Nonrecognition Modified by Estoppel}

Before the adoption of the Uniform Act, California by common law allowed collateral attacks upon divorces obtained upon sinulated domicile in other states. ${ }^{31}$ In this respect the Uniform Act is consistent with the prior law. But the common law allowed an innocent party to invoke the principles of estoppel to prevent the party who was guilty of inequitable conduct from maintaining his collateral attack. Thus, a party who had obtained a

${ }^{26}$ N. J. REv. STAT. \& 2:50-35 (1937):

... [P]rovided, that if any inhabitant of this state shall go into another state or country, in order to obtain a decree of divorce for a cause which occurred while the parties resided in this state, or for a cause which is not ground for divorce under the laws of this state, a decree so obtained shall be of no force or effect in this state.

This statute was taken from the Uniform Annulment of Marriage and Divorce Act of 1906. See TerRx, UnIForar State Laws Annotated 293 (1920). The two other states which adopted this act have followed divergent paths on the question of recognition of sister-state decrees. Delaware has repealed all statutory prohibitions on recognition; under the present provision, 45 LAwS OF DEL. c. 225, p. 906 (1945), unless common law standards of refusing recognition are adopted, foreign decrees are simply accorded full faith and credit. Any decisions on equitable defenses to collateral attacks upon sister-state decrees may thus be obviated by the simple device of not permitting any such attacks. Wisconsin, on the other hand, has adopted the Uniform Divorce Recognition Act [WIs. STAT. \$247.22 (1953)], althougb it had previonsly adopted the Uniform Annulment of Marriage and Divorce Act [WIs. STAT. § 247.21 (1953)]. Wisconson does not seem to have decided the question whether estoppel may be invoked against a collateral attack based upon either statute.

27 Sleeper v. Sleeper, 129 N.J.Eq. 94, 18 A.2d 1 (Ct. Err. \& App. 1941).

28 Judkins v. Judkins, 22 N.J. Super. 516, 92 A.2d 120 (Ch. 1952).

29 Weise v. Hughes, 1 N.J. Super. 104, 62 A.2d 694 (App. Div. 1948) ; Margulies v. Marguhies, 109 N.J.Eq. 391, 157 Atl. 676 (Ch. 1931).

30 Lawler v. Lawler, 2 N.J. 527, 66 A.2d 855 (1949) A similar holding in California may be found in Roberts v. Roberts, 81 Cal. App.2d 871, 185 P.2d 381 (1947). In Hollingshead v. Hollingshead, 91 N.J. Eq. 261, 110 Atl. 19 (Ch. 1920), the court maintained strenuously that there was no estoppel and that the decree could be challenged under any conditions; it was simply void. The facts of that case indicate, however, that the party atteinpting to raise the estoppel was himself guilty of inequitable conduct. He had caused his wife by fraud and duress to obtain a Nevada divorce without domicile in that state. He had appeared and answered in the Nevada action. The New Jersey court, although allowing the decree to be challenged, made it clear that it reserved power to deny affirmative rehef to a party ${ }^{\circ}$ who asserts the invalidity and whose conduct is unconscionable.

31 Crouch v. Crouch, 28 Cal.2d 243, 169 P.2d 897 (1946). 
decree in a state in which he had no domicile, ${ }^{32}$ or who aided another in procuring such a decree, ${ }^{33}$ or who relied upon such a decree to remarry or to marry one of the parties to it, ${ }^{34}$ or who claimed or accepted other benefits under it, ${ }^{35}$ would not be heard to impeach its validity in a subsequent proceeding to determine private rights. ${ }^{36}$ Does the Uniform Act overrule the cases which allowed estoppel in such circumstances?

Post-statute Law: The Dietrich Case

Two recent California decisions have considered the effect of the Uniform Act on the doctrine of estoppel. ${ }^{37}$ In the latest case, Dietrich v. Dietrich, ${ }^{38}$ the wife sought a decree of separate maintenance from her second husband, whom she had married immediately after a presumably invalid

32 Watson v. Watson, 39 Cal.2d 305, 246 P.2d 19 (1952); Rediker v. Rediker, 35 Cal.2d 796, 221 P.2d 1 (1950); but cf. Ryder v. Ryder, 2 Cal. App.2d 426, 37 P.2d 1069 (1934); and Kegley v. Kegley, 16 Cal. App.2d 216, 60 P.2d 482 (1936).

33 Bernheimer v. Bernheimer, 103 Cal. App.2d 643, 230 P.2d 17 (1951); Harlan v. Harlan, 70 Cal. App.2d 657, 161 P.2d 490 (1945); Estate of Davis, 38 Cal. App.2d 579, 101 P.2d 761, 102 P.2d 545 (1940). The Davis case relied upon the "conclusive presumption" of CaL. Code Crv. Proc. \$ 1962 (3). See text at note 55 infra.

34 Estoppel of a party to the decree because he remarried: Bruguierc v. Bruguiere, 172 Cal. 199, 155 Pac. 988, Ann. Cas. 1917E 122 (1916) ; Kelsey v. Miller, 203 Cal. 61, 263 Pac. 200 (1928); In re Kyle, 77 Cal. App.2d 634, 176 P.2d 96 (1947) ; Watson v. Watson, 39 Cal.2d 305, 246 P.2d 19 (1952); Hensgen v. Silberman, 87 Cal. App.2d 668, 197 P.2d 356 (1948); Bernheimer v. Bernheimer, supra note 33; cf. Wendell v. Wendell, 111 Cal. App.2d 899, 245 P.2d 342 (1952), where the jurisdictional defect was not lack of domicile in the renderimg forum, but rather want of fair notice of the action to the defendant spouse, and the court applied the estoppel rule, relying upon the Bruguiere case, supra. A literal interpretation of the Uniform Act may call for a distinction between types of jurisdictional defect in connection with the propriety of invoking an estoppel. (See text at notes 50-54 infra.)

Third party estopped because he married a party to the decree: Harlan v. Harlan, supra note 33; Estate of Davis, supra note 33; cf. Mumma v. Mumma, 86 Cal. App.2d 133, 194 P.2d 24 (1948).

35 Adoption of D. S., 107 Cal. App.2d 821, 236 P.2d 821 (1951).

30 Where the purpose of the collateral attack is merely to determine marital status, no estoppel will be invoked in California, even under common law rules, and the decree may be questioned by anyone with an interest, including the party who obtained it. In Estate of Hensgen, 80 Cal. App.2d 78, 181 P.2d 69 (1947), the wife was not estopped from asserting that she was decedent's lawful wife in order that she might claim and be appointed administratrix of his estate. However, in Hensgen v. Silberman, 87 Cal. App.2d 668, 197 P.2d 356 (1948), she was estopped from claiming any share in his estate as his widow, on grounds that she had remarried in reliance upon the void decree of divorce.

Compare the following Washington cases: Wampler v. Wampler, 25 Wash.2d 258, 170 P.2d 316 (1946); In re Tamke's Estate, 32 Wasli.2d 927, 204 P.2d 526 (1949). The Tamke case, while agreemg with the general rule denying estoppel in a procceding simply to determine marital status, holds that to be appointed administrator amounts to something more than such a determination, and so estops a first wife who claims such appoimtment.

${ }^{37}$ No cases in other jurisdictions have been found which deal with the question of estoppel under the Uniform Act. In California, three other important decisions have been rendered since the passage of the Act, and while they concern the general area of divorce recognition they do not appear to be in point for this paper: Watson v. Watson, 39 Cal.2d 305, 246 P.2d 19 (1952) (estoppel applied, but Uniform Act not mentioned in opimion) ; Huntington v. Huntington, 120 Cal. App.2d 705, 262 P.2d 104 (1953) (Act applied to loold invalid Nevada decree, but no elements of estoppel appear); Haden v. Haden, 120 Cal. App.2d 722, 262 P.2d 73 (1953) (full faith and credit accorded Nevada decree where defendant appeared but did not answer or produce evidence).

3841 Cal.2d 497, 261 P.2d 269 (1953); rehearing denied, October 22, 1953 ; cert. denied, 346 U.S. 938 (1954). 
Nevada divorce from her first husband in 1936. Defendant-second husband cross-complained for annulment, or, in the alternative, divorce, alleging the invalidity of the marriage and the divorce which preceded it. He had proposed marriage to plaintiff before she commenced her Nevada action and was at all times aware of the circumstances under which the decree in that case was rendered.

The Supreme Court of California held the defendant estopped from questioning the Nevada decree, because, ${ }^{39}$

With full knowledge of the circumstances under which that divorce was obtained, and in reliance on such divorce, Noah went through a marriage ceremony and hived with Carol as her husband.

As against Noah's attempted invocation of the policy of the Uniform Act in his favor, the court merely said, ${ }^{40}$

But we are not considering the "force or effect" of the Nevada decree except as such consideration is necessarily incident to the holding that Noah, because of his conduct in relation to that decree, has no standing to question it.

On its face the Dietrich decision seems to be a square holding that estoppel is available under the Uniform Act. Closer examination, however, indicates that it is such a holding only if the Act is deened to have retroactive effect, for the Nevada decree here preceded the adoption of the Uniform Act in California by sone thirteen years. If the Act does not have retroactive effect the result in the Dietrich case can be taken only to mean that the prior law of estoppel continues in effect as to cases governed by the prior common law of recognition in California, notwithstanding the enactment of the statute.

The Dietrich opinion gives no clear indication of whether the California court considers the Act retroactive, for apparently the court was urged only to consider as applicable the public policy expressed in the statute, instead of the nuandate of the Act itself. ${ }^{41}$ Nor is the answer to the question of retroactivity found in the legislative history of the statute. Since there is no evidence of the intent of the California legislature, the best source for determining the purpose of the statute is found in the expressions of the Commissioners on Uniform State Laws. The 1946 draft prepared by the Commissioners contained a provision that the Act should not apply to any divorce obtained in a proceeding begun prior to the effective date of the Act. ${ }^{42}$ This provision was deleted from the 1947 draft, which was approved by the American Bar Association. ${ }^{43}$ There is, however, a strong statutory argument for holding the Uniforn Act not to operate retroactively in California in the provision of section three of the Civil Code that

3941 Cal.2d at 505, 261 P.2d at 273.

40 Id. at 505,261 P.2d at 273.

41 "Noah urges that the public policy applicable here is that stated in Section 150.1 of the Civil Code ...." [Emphasis added.] Id. at 505, 261 P.2d at 273.

42 HandBook of THE National Conference of Commisstoners on UntForm State Laws 190 (1946).

439 UNIFORM LAwS, ANNOTATEd 365 (1951). 
no part of the Code is retroactive unless expressly so declared. ${ }^{44}$ There is no such declaration for the Uniform Act; hence, if section three is to be given effect, it would appear that foreign decrees obtained prior to the effective date of the Uniform Act are still governed by the prior common law of recognition.

\section{The Gordon Case}

Because the supreme court's decision in the Dietrich case may not hold that estoppel is available under the Uniform Act, the earlier decision of the District Court of Appeal in Union Bank and Trust Company v. Gordon ${ }^{45}$ may gain importance. Here $\mathrm{H}$ obtained an ex parte Nevada divorce in 1929, while he was domiciled in California and $W$ was domiciled in New York. Both parties remarried in reliance upon the decree. W later had her second marriage annulled in New York on grounds of fraud of her second husband. ${ }^{46}$ When $H$ died in 1950, $W$ claimed part of his estate, asserting that she was his lawful widow. Plaintiff brought this action as special administrator of H's estate, interpleading W and H's second, "putative" spouse, and praying an adjudication of their rights.

The trial court found that H's second marriage was void, that $W$ was not estopped to challenge its validity or barred by laches, and that she was entitled to a one-half interest in the property of the second marriage. The District Court of Appeal reversed and adjudged the putative widow to be entitled to all of the property of the second marriage.

W had attempted to invoke the Uniform Act in her favor to challenge the Nevada decree and H's second marriage which was based upon it. The court was willing to assume that the Nevada decree was invalid in California; nevertheless, it refused to permit $W$ to raise the issue. ${ }^{47}$ The court said, ${ }^{48}$

The rule of estoppel has never been considered by the courts of this state to be inconsistent with the rule that a foreign divorce decree obtained on simulated residence has no force or effect. [Citation omitted.] In applying the rule of estoppel the courts have assumed that the decree was invalid and therefore of no force or effect. [Citation omitted.] We caimot hold that a mere statutory declaration of what had therefore been a rule of decision is so inconsistent with the rule of estoppel as to preclude application of the latter rule.

44 This has been construed to include additions to the Code made after the 1872 enactment. Estate of Frees, 187 Cal. 150, 201 Pac. 112 (1921); Aetna Casualty \& Surety Co. v. Industrial Accident Commission, 30 Cal.2d 388, 182 P.2d 159 (1947).

45116 Cal. App.2d 681, 254 P.2d 644 (1953).

46 In that action the New York court found that the parties had been "duly married." Seemingly the Nevada decree was never challenged in New York. Id. at 683,254 P.2d at 645 . 47 "To refuse to permit Sara to contest the validity of the Nevada decree does not mean that the courts of this state recognize the Nevada decree as valid, but only that it is not open to her in this action to say it is void." Id. at 685,254 P.2d at 647 .

$48 I d$. at 686,254 P.2d at 647 . The court also said that the rule of estoppel is not inconsista. ent with the Uniform Act. Although this would be strong dictun for the position that estoppel is available under the Act, the ready distinguishability of tbe Gordon case, on the issue of the scope of the "both parties" phrase (see text at note 50 infra), seems to call for stronger authority for the point. 
And further:" "We hold that Civil Code, section 150.1, does not prevent application of the rule of estoppel."

The Gordon case, like the Dietrich case, cannot be taken to mean that estoppel is available under the Uniform Act, for it, too, is distinguishable if the Act is not held retroactive. The Gordon case is also distinguishable from any holding that estoppel may be invoked under the statute if the Act's scope of applicability is limited to what is expressed in its language. The Act applies only where both spouses are California domiciliaries at the time the sister-state divorce action was commenced. ${ }^{50}$ In the Gordon case, however, only one of the parties was so domiciled. Is the phrase "both parties" to be interpretatively expanded to mean "one party"? To apply the statute in the circumstances of the Gordon case the court implicitly must do just that. Without such construction, the case would seem to hold, not that estoppel has survived the adoption of the Act, but only that estoppel is still available in cases governed by the common law and not by the Uniform Act.

In the event that the Gordon case is taken to mean that "both parties" does mean "one party," one may question what limits will be placed upon the scope of the Act. Will it be extended to eliminate estoppel in the case where neither party is domiciled in California? This result is conceivable if the Act is held to preclude estoppel and the strained construction of its scope implicit in the Gordon opinion is not corrected. Hence, short of a holding that the Act has not changed the law of estoppel, it is believed that a judicial construction of the words, "both parties," is needed to clear away the doubts raised by the implied expansion of their meaning in the Gordon case.

RESOLVING THE UNCERTAINTY: SHOULD ESTOPPEL BE RETAINED?

As indicated above, no clear answer lias yet been given to the central question whether the Uniform Act has eliminated estoppel in the California law of divorce recognition. The history of the Uniform Act reveals a purpose on the part of its draftsmen to abolish the doctrine or at least to reduce its effect upon the state law of recognition. There are, however, several considerations which militate against this result.

First of all, to hold that the Uniform Act abolishes estoppel in cases which it governs will create unjustifiable inconsistencies in the California law of recognition. If, on the one hand, the Act is construed literally, ${ }^{51}$ as covering only the situation wliere both parties were Californians at the time the divorce action was commenced, estoppel would still be allowed in the other cases left for determination by the prior rules of decision. ${ }^{52}$ Whether the particular case is ruled by the statute or not, the central fact is that the decree is void because the spouse who obtained it had not established a bona fide domicile in the divorce forum. It is hardly justifiable to cause the

49 Id. at 688,254 P.2d at 649 .

50 Car. Civ. Code $\$ 150.1$.

51 See text at note 50 supra. 
permissibility of estoppel to turn upon a fact so manifestly incidental as whether the defendant spouse had California domicile at the time of the divorce action.

On the other hand, if the Uniform Act is broadly construed, so as to govern all decrees void on domicile grounds, still the Act would leave intact the applicability of estoppel in cases involving jurisdictional defects other than lack of domicile, as, for example, extrinsic fraud. No basis in principle appears for such a distinction. Certainly the conduct of the party who leaves California for a state where divorces are quick and easy, intending to return here when he has obtained his decree, is no more reprehensible than the conduct of one who misrepresents the address of his spouse, in case of service by publication, in order to obtain an uncontested decree. ${ }^{\text {b3 }}$ The distinction would be a novel one, for the case law seems to have recognized that the same principles were applicable, upon collateral attack, whatever the source of the jurisdictional defect in the challenged decree..$^{\text {st }}$

Finally, it may be urged that the continued allowance of estoppel, even in cases governed by the Uniform Act, finds support in Section 1962(3) of the California Code of Civil Procedure. That section provides a rule of evidence precluding a party from denying the truth of his own declaration, act, or omission in any litigation arising out of such declaration, act, or omission, where the opposing party has relied upon it. The provision has been used to work an estoppel against a party attempting to invoke a common law rule of nonrecognition to impeach a sister-state divorce, ${ }^{65}$ and it might well be so used under the Uniform Act.

\section{CONCLUSION}

The sole impact of the Uniform Divorce Recognition Act upon the California law (outside of its provision of a standard of evidence of domicile in this state ${ }^{56}$ ) appears to lie in the possible abolition of the estoppel doctrine from that portion of the law of recognition governed by the Act. Al-

52 There are various possibilities: (1) one spouse is domiciled in California and the other in state $A$, and the Californian obtains an ex parte decree in state $B$ without acquiring domicile there; (2) the spouses are domiciled as above, and the spouse domiciled in state A procures the decree in state $B$; (3) neither is domiciled in California nor in the rendering forum, the decree is obtained ex parte, and the plaintiff later moves to Cahforma, where the decree is challenged.

53 The due process considerations which underly the invalidity of a decree obtained by extrinsic fraud seem at least as strong as the considerations which cause a decree obtained without domicile to be invalid. The justification for the later rule is often asserted to be that the state has an interest in the matrimonial status of its domiciliary, which interest it may protect in its own courts. See Williams v. North Carolina (II), 325 U.S. 226 (1945); cf. Alton v. Alton, 207 F.2d 667 (3d Cir. 1953), vacated and dismissed as moot, 347 U.S. 610 (1954).

54 Wendell v. Wendell, 111 Cal. App.2d 899, 245 P.2d 342 (1952); in Parmelee v. Hutchins, 238 Mass. 561, 131 N.E. 443 (1921), the court applied estoppel in an extrinsic fraud case and relied on a domicile case as authority. See discussion in text and notes at notes 24-25 supra.

55 Estate of Davis, 38 Cal. App.2d 579, 101 P.2d 761, 102 P.2d 545 (1940). Sce notes in 19 Am. Jur. 811, $\$ 155(1940)$. The Gordor opinion contained a passing mention of the provision, but the court preferred to base its holding directly upon the judicially developed doctrine of estoppel.

56 See note 14 supra. 
though this result may have been intended by the original draftsmen of the Uniform Act, it has not yet been accepted by the California courts. On the contrary, dicta in the only two cases which have dealt with this aspect of the Act indicate a disposition to regard the law of estoppel as unchanged. The following considerations lend support to this approach: (1) the judiciary has found it in the interests of justice to allow estoppel, although espousing the very policy of nonrecognition of decrees secured on simulated domicile expressed in the Act; (2) there is another statute in California which supports the continuance of estoppel; ${ }^{57}$ and (3) the abolition of estoppel would create unjustified inconsistencies in the California law of recognition of sister-state divorce decrees. The policy of nonrecognition of the migratory divorce, whether enforced by rule of decision or by statute, does not compel discarding the estoppel doctrine and affording a party whose conduct has been unconscionable an opportumity of attacking the decree.

Norman G. Rudman 